\title{
Characterization of a New Small Bowel Adenocarcinoma Cell Line and Screening of Anti-Cancer Drug against Small Bowel Adenocarcinoma
}

Hirobumi Suzuki, Yoshihiro Hirata, Nobumi Suzuki, Sozaburo Ihara, Kosuke Sakitani, Yuka Kobayashi, Hiroto Kinoshita, Yoku Hayakawa, Atsuo Yamada, Hirotsugu Watabe, Keisuke Tateishi, Tsuneo Ikenoue, Yutaka Yamaji, and Kazuhiko Koike

Accepted for publication October 2, 2014.

Address correspondence to Yoshihiro Hirata, M.D., Ph.D., or Hirobumi Suzuki, M.D., Ph.D., 7-3-1 Hongo, Bunkyoku, Tokyo 113-8655, Japan. E-mail: hiratay-int@h.u-tokyo. ac.jp or suzuhiro817@yahoo. co.jp.

\begin{abstract}
Small bowel adenocarcinoma (SBA) is a rare, aggressive malignancy with a poor prognosis, and the mechanisms of carcinogenesis in SBA remain unclear. Our aims were to investigate the molecular mechanisms underlying SBA and to identify treatments by establishing and characterizing an SBA cell line and performing anti-cancer drug screening. SIAC1 cells, established from jejunal SBA, showed epithelial characteristics and formed organoids in 3D culture. SIAC1 cells had a heterozygous $\beta$-catenin deletion mutation, resulting in a stable $\beta$-catenin protein with enhanced Wnt/ $\beta$-catenin activity. SIAC1 cells lacked MLH1 and MSH6 expression, and target genes such as TGFBR2 and ACVR2 showed frameshift mutations. Among 10 clinical SBA samples, $2(20 \%)$ had interstitial deletions in $\beta$-catenin, expression of mismatch repair protein was aberrant in $4(40 \%)$, and heterozygous frameshift mutations of three target genes were found in all 10 samples. On screening assay using 140 compounds, eribulin significantly inhibited SIAC1 cell growth both in vitro and in vivo by inhibition of the Wnt/ $\beta$-catenin pathway via enhanced degradation of $\beta$-catenin. In conclusion, we established an SBA cell line with molecular characteristics similar to those of clinical SBA samples, including $\beta$-catenin deletion and mismatch repair protein deficiency, that will be useful for SBA research. Eribulin might be a candidate for SBA treatment due to its inhibitory effect on Wnt/ $\beta$-catenin signaling. (Am J Pathol 2015, 185: 550-562; http://dx.doi.org/10.1016/j.ajpath.2014.10.006)
\end{abstract}

Small bowel adenocarcinoma (SBA) is a rare and aggressive malignancy with a poor prognosis. The small intestine constitutes approximately $75 \%$ of the length of the entire gastrointestinal tract, but primary SBA occurs in only $<2 \%$ to $3 \%$ of gastrointestinal cancers. ${ }^{1}$ It is difficult to detect early stage SBA because the small bowel is distal from the mouth and anus, although recently, new technologies such as capsule endoscopy and double-balloon endoscopy have enabled early detection, diagnosis, and endoscopic treatment. ${ }^{2-4}$ Despite the development of these techniques, the diagnosis of SBA is often delayed due to nonspecific symptoms such as abdominal pain, nausea, vomiting, and anemia. Current National Comprehensive Cancer Network guidelines recommend that SBA be treated similarly to colorectal cancer (CRC), with surgical resection as the primary treatment. ${ }^{5}$

SBA has many etiological, morphological, and genetic features in common with CRC. Both cancers are associated with the same carcinogens, such as red meat, alcohol, and tobacco. $^{6}$ Like CRC, an increased frequency of SBA is also related to genetic disorders such as familial adenomatous polyposis, Lynch syndrome, and Peutz-Jeghers syndrome, as well as Crohn disease and celiac disease. CRC and SBA undergo a histological progression similar to that of invasive cancer, through adenomas mediated by the adenoma-carcinoma sequence. 8,9 Despite the many similarities between SBA and CRC, the prevalence of SBA is 60- to 70-fold less than that of CRC. ${ }^{10}$ Moreover, the 5 -year survival rate of SBA is $37 \%^{11}$ compared with $65 \%$ with CRC. ${ }^{12}$

Two types of genomic instability, chromosomal instability and microsatellite instability (MSI), are closely associated

Supported by Grant-in-Aid for Scientific Research 24590931 (A.Y. and Y.Hi.).

Disclosures: None declared. 
with carcinogenesis throughout the gastrointestinal tract. ${ }^{13}$ Chromosomal instability is defined as an aberrant genomic status with chromosomal aneuploidy and is found in $50 \%$ to $70 \%$ of CRCs and $60 \%$ of SBAs, reportedly. ${ }^{14,15}$ MSI is caused by the mismatch repair (MMR) genes MLH1, MSH2, MSH6, PMS1, and PMS2, which are considered to be causative of Lynch syndrome. ${ }^{16}$ MSI is further associated with carcinogenesis through replication errors in target genes such as TGFBR2, $A C V R 2$, and MARCKS. ${ }^{17,18}$ This pathway is more prevalent in SBA, $20 \%$ to $45 \%$, compared with $15 \%$ in CRC. ${ }^{13,19-21}$ Epigenetic changes, such as DNA hypermethylation, are also associated with gastrointestinal carcinogenesis. ${ }^{22}$ In particular, the $\mathrm{CpG}$ island methylator phenotype (CIMP) has been increasingly recognized in sporadic CRC and SBA. ${ }^{14,15,23}$ The methylation status of the promoters for pl6INK4A, MLH1, and MGMT has been related to carcinogenesis, as well as invasion and metastasis. ${ }^{15,24}$

Although the characteristics of SBA have been identified in resected specimens, the lack of an SBA cell line has made it difficult to determine the molecular mechanisms of SBA carcinogenesis or to establish potential SBA treatment strategies. In this study, we established and characterized an SBA cell line and assessed the anti-cancer effects of candidate drugs.

\section{Materials and Methods}

\section{Patient Specimens}

We analyzed eight surgical specimens and three biopsy specimens from small bowel cancers, excluding ampullary tumors, diagnosed at Tokyo University Hospital (Tokyo, Japan) from June 2005 to May 2013. The specimens were obtained with written informed consent from the patients ( $n=11$; mean age, $54.5 \pm 19.9$ years; five male patients). All procedures were approved by the ethics committee of the medical faculty at the University of Tokyo, in accordance with generally accepted guidelines for the use of human material.

\section{Establishment of SIAC1 Cells}

For the establishment of a cell line termed small intestinal adenocarcinoma 1 (SIAC1), SBA biopsy specimens were cut into small pieces in digestion medium containing $360 \mathrm{U}$ collagenase (Wako Pure Chemical Industries, Ltd., Osaka, Japan) and 3.75-U dispase (Wako) in $3 \mathrm{~mL}$ of Dulbecco's modified Eagle's medium (Gibco-Life Technologies, Grand Island, NY). The sample was incubated for $40 \mathrm{mi}-$ nutes at $37^{\circ} \mathrm{C}$, washed with phosphate-buffered saline containing $1 \%$ fetal bovine serum, resuspended in $25 \%$ Ham's F12 medium, 25\% Dulbecco's modified Eagle's medium, and 50\% RPMI medium mixture containing 20\% fetal bovine serum and seeded into a 48 -well microplate. After culturing for 10 to 14 days, a small colony was detected and transferred to a larger microplate. We had tried to establish SBA cell lines in eight patients, and only one cell line was successfully established.

\section{Cell Lines, Antibodies, and Anti-cancer Drugs}

Cells from an SBA line (SIAC1), CRC lines (HT29, Lovo, DLD1, Hct116, RKO), and human embryonic kidney line (HEK293T) were used in this study. All cell lines were cultured at $37^{\circ} \mathrm{C}$ with $5 \% \mathrm{CO}_{2}$ in the indicated media (Supplemental Table S1). RSpo1-Fc HEK293T cells were kindly provided by Toshiro Sato (Keio University, Tokyo, Japan) with permission from Calvin Kuo (Stanford University, Palo Alto, CA). ${ }^{25}$ The antibodies and anticancer drugs used in this study are listed in Table 1 and Supplemental Table S2, respectively. The Screening Committee of Anti-cancer Drugs kindly provided inhibitor kits 3 and 4 .

\section{D Culture of SIAC1 Organoids}

SIAC 1 cells $\left(3.0 \times 10^{2}\right.$ cells/well $)$ were suspended with $25 \mu \mathrm{L} /$ well of cold Matrigel and piled up quickly to a 48-well microplate warmed to $37^{\circ} \mathrm{C}$. After incubation at $37^{\circ} \mathrm{C}$ for 5 minutes, Matrigel containing SIAC1 cells was soaked up with $500 \mu \mathrm{L} /$ well of ENR $(50 \mathrm{ng} / \mathrm{mL}$ of murine epidermal growth factor, $100 \mathrm{ng} / \mathrm{mL}$ of murine Noggin, human R-spondin-1 condition medium) or EN (without human R-spondin-1 condition medium) culture medium. ${ }^{26}$ Medium change was performed every 3 days, and the organoids were harvested for histological examination and immunohistochemistry (IHC) analysis 2 weeks after cultivation.

\section{Genomic, Complementary, and Plasmid DNA Preparation}

Genomic DNA was extracted from cell lines and $10 \mu \mathrm{m}$ of paraffin-embedded SBA samples using the QIAmp DNA Mini Kit and QIAmp DNA Formalin-Fixed, ParaffinEmbedded Tissue Kit, respectively (Qiagen, Hilde, Germany). Total cellular RNA was prepared using the NucleoSpin RNA II kit (Takara Bio Inc., Tokyo, Japan). The Improm-II Reverse Transcription System (Promega Corp., Madison, WI) was used for preparing complementary DNA. Plasmid DNA was prepared using the GenElute HP Plasmid Miniprep Kit (Sigma-Aldrich, St Louis, MO). All procedures were performed according to the manufacturers' recommended protocols.

\section{Mutational Analysis of Proto-Oncogenes}

$B R A F$ exon 15, KRAS exon 2 (coding exon 1), APC exon 15 peripheral mutation cluster region, $\beta$-catenin gene (CTNNB1) exons 1 to 6, and EGFR exons 18, 19, 21, and 23 were analyzed for mutations by direct sequencing as 
Table 1 Antibodies Used in This Study

\begin{tabular}{llll}
\hline Immunogen & Host & Product & Manufacturer \\
\hline Pan-cytokeratin (panCK) & Rabbit & H-240 & Santa Cruz Biotechnology, Inc. (Santa Cruz, CA) \\
$\alpha$-Smooth muscle actin ( $\alpha$-SMA) & Mouse & 1 A4 & Dako (Glostrup, Denmark) \\
Mucin-2 (MUC2) & Mouse & Sc-7314 & Santa Cruz Biotechnology \\
$\beta-A c t i n$ & Mouse & AC-15 & Sigma-Aldrich (St Louis, M0) \\
MLH1 & Mouse & 554073 & Becton, Dickinson, and Company (Franklin Lakes, NJ) \\
MSH2 & Mouse & Ab-2 & Calbiochem (Darmstadt, Germany) \\
MSH6 & Rabbit & EPR3945 & Abcam (Cambridge, UK) \\
PMS1 & Rabbit & C-20 & Santa Cruz Biotechnology \\
PMS2 & Mouse & C-20 & Santa Cruz Biotechnology \\
$\beta-C a t e n i n$ & Rabbit & $6 B 3$ & Cell Signaling Technology, Inc. (Beverly, MA) \\
$\beta-C a t e n i n$ & Mouse & 610153 & Becton, Dickinson, and Company \\
SMAD4 & Mouse & B-8 & Santa Cruz Biotechnology \\
p53 & Rabbit & FL-393 & Santa Cruz Biotechnology \\
TGF $\beta$ R2 & Rabbit & L-21 & Santa Cruz Biotechnology \\
FLAG & Mouse & F1804 & Sigma-Aldrich \\
MLH1 for IHC & Mouse & 550838 & Becton, Dickinson, and Company \\
C-MYC & Rabbit & 9402 & Cell Signaling Technology \\
Cyclin D1 & Mouse & DCS-6 & Santa Cruz Biotechnology \\
Ki-67 & Mouse & MIB-1 & Dako \\
\hline
\end{tabular}

IHC, immunohistochemistry.

described previously. ${ }^{27}$ The primers are shown in Table 2. Conventional PCR was performed on the MyCycler PCR system (Bio-Rad Laboratories, Inc., Hercules, CA), as follows: an initial denaturing step for 10 minutes at $95^{\circ} \mathrm{C}$, followed by 40 cycles at $95^{\circ} \mathrm{C}$ for 45 seconds, $56^{\circ} \mathrm{C}$ to $64^{\circ} \mathrm{C}$ for 45 seconds, and $72^{\circ} \mathrm{C}$ for 30 seconds. Data analysis was performed using the Genetyx version 9 software (Genetyx Corp., Tokyo, Japan).

\section{MSI and Target Gene Analysis}

We analyzed the MSI pattern using the following five standard microsatellite markers: BAT25, BAT26, D2S123, $D 2 S 346$, and $D 17 S 250 .{ }^{28}$ The primers and thermal cycling protocols were referred to in a previous report. ${ }^{29}$ Microsatellite sequences of the potential target genes were analyzed by direct sequencing analysis and TA cloning using TOPO TA Cloning Kits (Life Technologies Corp., Carlsbad, CA) according to the manufacturer's protocol. The primers for the target gene analysis are shown in Table 2.

\section{Quantitative PCR}

For MMR expression analysis, cDNA was prepared from SIAC1 and RKO cells treated with the indicated amount of 5-aza-2-deoxycytidine (5-aza-dc) for 96 hours and/or 0.5 $\mu \mathrm{mol} / \mathrm{L}$ of trichostatin A for 24 hours. Then, $5 \mu \mathrm{L}$ of cDNA was used in $12.5 \mu \mathrm{L}$ reactions containing SYBR Green Master Mix (PE Applied Biosystems, Foster City, CA) and $400 \mathrm{nmol} / \mathrm{L}$ of gene-specific primer for the target gene or reference gene (glyceraldehyde 3-phosphate dehydrogenase; GAPDH ). The primer sequences are described in Table 2. Quantitative PCR was performed twice in duplicate samples using an ABI Prism 7000 real-time PCR system (Life Technologies).

\section{Methylation-Specific PCR of MLH1 Gene}

SIAC1, HT29, and RKO genomic DNA were treated with a EpiTect bisulfite kit (Qiagen) according to the manufacturer's instructions, and $20 \mathrm{ng}$ of the bisulfite-modified DNA was used for methylation-specific PCR. The specific primer sets for methylated or unmethylated $M L H 1$ promoter are shown in Table 2. PCR reactions were started at $95^{\circ} \mathrm{C}$ for 5 minutes. Amplification was performed for 42 cycles $\left(95^{\circ} \mathrm{C}\right.$ for 30 seconds, $56^{\circ} \mathrm{C}$ for 30 seconds, and $72^{\circ} \mathrm{C}$ for 30 seconds) and followed by a final extension at $72^{\circ} \mathrm{C}$ for 10 minutes.

\section{Preparation and Analysis of a $\beta$-Catenin Deletion Mutant}

A FLAG-epitope tagged $\beta$-catenin deletion mutant (MUT) was generated from the wild-type (WT) $\beta$-catenin using the KOD -Plus- Mutagenesis Kit (Toyobo Co., Ltd., Osaka, Japan). The primer sequences for generating MUT from WT are shown in Table 2. HEK293T cells were cultured in 12 -well plates $\left(2.0 \times 10^{5}\right.$ cells/well $)$ for 24 hours and transfected with $0.3 \mu \mathrm{g}$ of WT or MUT vector using Effectene (Qiagen). Cells were harvested 48 hours after transfection and prepared for Western blot analysis.

\section{Western Blot Analysis}

Total protein was extracted from cultured cells using a lysis buffer that contained $50 \mathrm{mmol} / \mathrm{L}$ of Tris- $\mathrm{HCl}(\mathrm{pH}$ 7.4), $1 \%$ Triton $\mathrm{X}-100,5 \mathrm{mmol} / \mathrm{L}$ of EDTA, $1 \mathrm{mmol} / \mathrm{L}$ of 
SBA Line for Anti-Cancer Drug Screening

Table 2 Sequence of Primers for PCR Mutation Analysis and MSI Target Gene Analysis

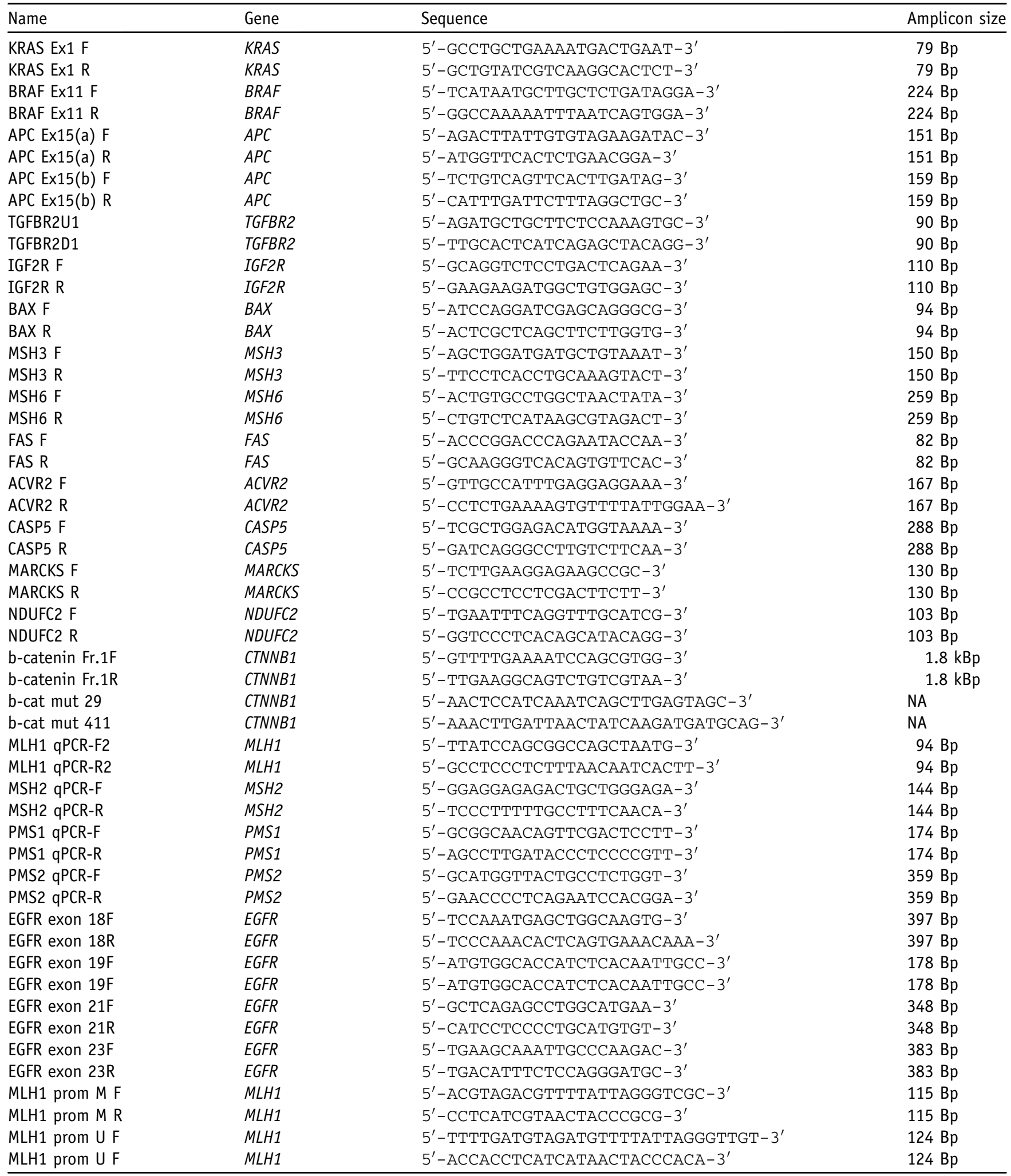

EGFR, epidermal growth factor receptor; F, forward; MSI, microsatellite instability; NA, not applicable; qPCR, real-time quantitative PCR; R, reverse.

$\mathrm{Na}_{3} \mathrm{VO}_{4}$ and protease inhibitor cocktail tablets [cOmplete Mini (F. Hoffmann-La Roche, Ltd., Basel, Switzerland)] (1 tablet/10 mL). For the evaluation of protein stability, cells were treated with $10 \mu \mathrm{g} / \mathrm{mL}$ cycloheximide (Wako) for the indicated time. The lysate was centrifuged for 10 minutes at 10,000 rpm, and the supernatant was collected as total protein. Western blot analysis was performed as described previously. ${ }^{27}$ 


\section{Reporter Gene Assay}

SIAC1, RKO, HT29, and Hct1 16 cells were grown in 48-well plates until $60 \%$ to $70 \%$ confluence. The luciferase-reporter plasmids pTOP-Flash, pFOP-Flash, or pD1luc $(0.15 \mu \mathrm{g} /$ well) were mixed with $0.4 \mu \mathrm{g} /$ well of thymidine kinase promoter-Renilla luciferase reporter plasmid, which was used to correct for transfection efficiency. Transfection was performed using Effectene transfection reagent (Qiagen) according to the manufacturer's protocol. Reporter gene activity was assessed after 48 hours using PicaGene Dual (Toyo B-Net Co., Ltd., Tokyo, Japan) in triplicate. Representative data from more than three experiments are shown.

\section{Immunofluorescence}

SIAC1 or HT29 cells were seeded into two- or four-well plastic chamber slides (Thermo Fisher Scientific, Rochester, NY). The cells were washed with phosphate-buffered saline, fixed with $4 \%$ paraformaldehyde for 10 minutes, permeabilized with $0.2 \%$ Triton X-100 (Sigma-Aldrich) for 5 minutes, and then blocked with 5\% goat normal serum for 1 hour at room temperature. Primary antibodies were added, followed by incubation overnight at $4^{\circ} \mathrm{C}$. Detection was performed as described previously. ${ }^{27}$

\section{IHC Analysis}

Formalin-fixed, paraffin-embedded small bowel specimens and SIAC1 organoids were cut to a thickness of $3 \mu \mathrm{m}$ and deparaffinized. After boiling with antigen retrieval buffer (10 $\mathrm{mmol} / \mathrm{L}$ of citric acid monohydrate, $\mathrm{pH} 6.0$ ) for 20 minutes, endogenous peroxidase activity was blocked using $3 \% \mathrm{H}_{2} \mathrm{O}_{2}$. The primary antibody was added, and incubated overnight. Subsequent immunostaining was conducted using the Vectastain Elite ABC Kit (Vector Laboratories, Burlingame, CA), following the manufacturer's instructions. The staining was developed by reaction with Histofine Simple Stain Diaminobenzide solution (Nichirei Biosciences, Tokyo, Japan), followed by counterstaining with hematoxylin. For SIAC1 organoids, rhodamine-conjugated Ulex europaeus agglutinin I lectin (1:1000; Vector Laboratories) was mixed with primary antibody:anti-MUC2 antibody, and Alexa Fluor 488 goat anti-mouse $\operatorname{IgG}(1: 400$, A11001; Invitrogen, Carlsbad, CA) was used as secondary antibody. Nucleic acid staining was performed by Hoechst33342 (1:1000; Doujin Chemical Co., Kumamoto, Japan).

\section{Cell Proliferation Assay}

For anti-cancer drug screening, SIAC1 cells were seeded at $3.0 \times 10^{3}$ cells per well in flat-bottomed 96-well microplates. After 48 hours, cells were treated with $10 \mu \mathrm{mol} / \mathrm{L}$ of the anti-cancer drugs listed in Supplemental Table S2 for the indicated times. The cells were enumerated using the Cell Counting Kit-8 (Doujin Chemical Co.).

\section{Tumor Xenograft Model}

Nude mice were purchased from Clea Japan, Inc. (Tokyo, Japan) and were inoculated s.c. at four sites in the back with $3.0 \times 10^{6}$ SIAC1 cells per site as described previously. ${ }^{30}$ After 2 weeks, the mice were randomly assigned to receive bortezomib $0.1 \mathrm{mg} / \mathrm{kg}$ i.p. b.i.w., eribulin $0.25 \mathrm{mg} / \mathrm{kg}$ i.p. t.i.w., or saline (control) i.p. t.i.w., as described previously. ${ }^{31,32}$ We measured the largest diameter of the s.c. tumor every 3 days, and the volume of each tumor was calculated according to the following formula: volume $=4 \pi \mathrm{r}^{3} / 3$, where $\pi=$ circular constant and $r=$ half of largest diameter. The experimental protocols were approved by the Ethics Committee for Animal Experimentation at the University of Tokyo and were performed in accordance with the guidelines for the Care and Use of Laboratory Animals of the Graduate School of Medicine, the University of Tokyo.

\section{Statistical Analysis}

Statistical analysis was performed using the Student's $t$-test, two-sided, or one-way analysis of variance with the Dunnett multiple-comparison test, or the Tukey honestly significant difference test. Differences were considered statistically significant if the $P$ value was $<0.05$. Data analysis was performed using JMP Pro version 10.0.2 software (SAS institute Japan Inc., Tokyo, Japan).

\section{Results}

\section{Establishment and Characterization of SIAC1 Cells}

A cell line was established from SBA tumor of 70-year-old woman who had no history of Lynch syndrome, celiac disease, and Crohn's disease or family history of inherited disease. The original tumor was jejunal adenocarcinoma located about $5 \mathrm{~cm}$ from the ligament of Treitz. The SIAC1 cells displayed a short, polygonal, and epithelial-like morphology (Figure 1A). Western blot analysis demonstrated that PanCK, but not $\alpha$-small muscle actin (SMA), was present in SIAC1 cells, as well as in the CRC cell line, HT29 (Figure 1B). These results verified that SIAC1 cells were derived from intestinal epithelial cells. SIAC1 cells also grew in 3D culture condition (Figure 1C), which has been reported in CRC cells. ${ }^{33}$ When cultured in Matrigel, SIAC1 cells formed cystic organoids with budding structures. IHC analysis showed that a few SIAC1 cells differentiated into MUC2 or Ulex europaeus agglutinin I lectin-positive secretory cells, suggesting their intestinal cell origin (Figure 1C).

Aberrant MMR gene expression is frequently found in SBA. ${ }^{13,21}$ Therefore, we evaluated MMR expression in SIAC1 cells. MLH1 and MSH6 expression was deficient and MSH2 expression was reduced in SIAC1 cells (Figure 1D). PMS1 and PMS2 expression levels were also decreased compared with those in the HT29 cells, which are known to have normal MMR gene expression. ${ }^{34}$ Findings on immunofluorescence for MLH1 
A

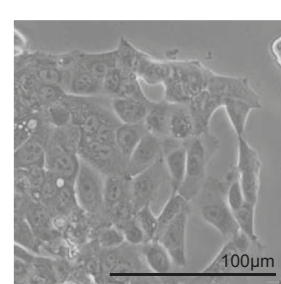

B

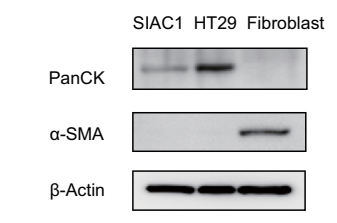

D

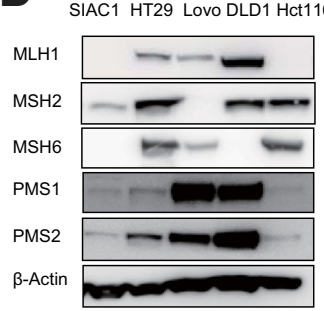

E

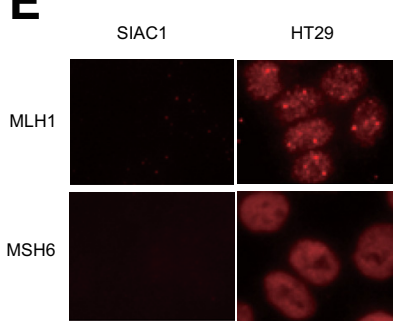

C

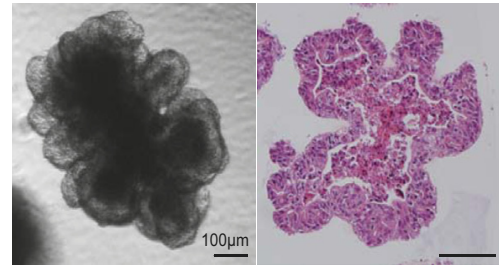

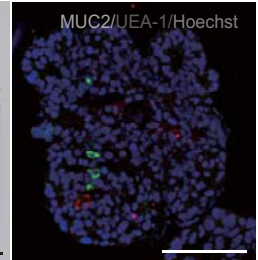
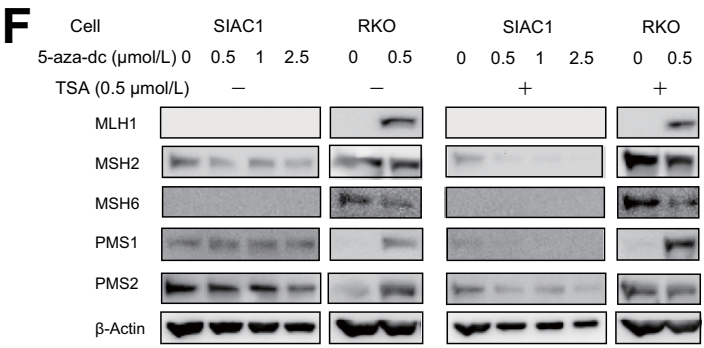

G

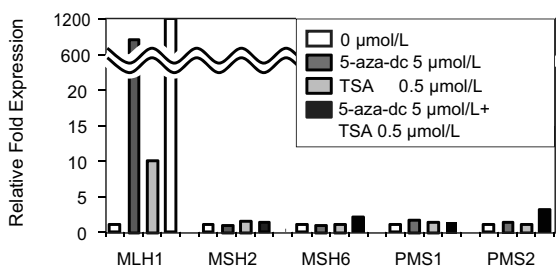

H

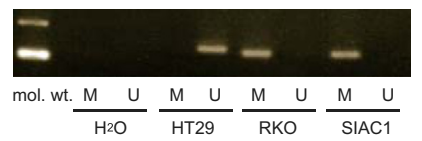

Figure 1 Characterization of SIAC1 cells established from adenocarcinoma of the jejunum. A: Photomicroscopy of SIAC1 cells. B: Western blot analysis of $\alpha$-smooth muscle actin ( $\alpha$-SMA) as a fibroblast marker and pan-cytokeratin (panCK) as an epithelial marker in SIAC1, HT29, and human fibroblast cells. C: SIAC1 cells form organoids. Photomicroscopy (left) and hematoxylin and eosin staining (middle) of SIAC1 organoids cultured for 14 days. Double-staining of anti-MUC2 (green) and rhodamine-conjugated Ulex europaeus agglutinin I lectin (red) for goblet cells (right). Nuclear staining was performed by Hoechst 33342 (blue). D: SIAC1 and human colorectal cancer cell lines were analyzed for mismatch repair (MMR) expression by Western blot analysis. HT29 cells are microsatellite stable. Lovo, DLD1, and Hct116 cell lines lack MSH2, MSH6, and MLH1 expression, respectively. E: Immunofluorescence microscopy of SIAC1 cells for MMR proteins. F: MMR expression was analyzed by Western blot analysis in SIAC1 and RKO cells treated with the indicated concentrations of 5-aza-2-deoxycytidine (5-aza-dc) alone or with trichostatin A (TSA). G: Relative MMR mRNA levels were analyzed in SIAC1 cells treated with 5-aza-dc and/or TSA by real-time PCR. The ratio was calculated relative to the basal mRNA level in control SIAC1 cells. H: Methylation-specific PCR for the MLH1 promoter. Bisulfite-modified genomic DNA was amplified with unmethylated $(\mathrm{U})$ and methylated $(\mathrm{M})$ specific primer sets. $\mathrm{H}_{2} \mathrm{O}$ represents blank control. $\mathrm{HT} 29$ and RKO are positive controls for unmethylated and methylated cell lines, respectively. Original magnification: $\times 200$ (A and C, right); $\times 100$ (C, middle); and $\times 40$ (C, left); $\times 400$ (E).

and MSH6 correlated with the findings from the Western blot analysis (Figure 1E), suggesting that altered MMR gene expression was involved in the development of SIAC1 cells.

Since MMR deficiency causes MSI, we examined MSI markers in SIAC1 cells. MSI analysis showed that all five markers-BAT25, BAT26, D2S123, D2S346, and $D 17 S 250^{28}$ - were positive in SIAC1 cells, indicating this cell line to be MSI-high $(\mathrm{H})$. Regarding MSI target genes in SIAC1, we found monoallelic frameshift mutations in $B A X$, MSH3, CASP5, TGFBR2, and MARCKS, whereas ACVR2 and MSH6 had bi-allelic frameshift mutations. No mutations were detected in the FAS, IGF2R, and NDUFC2 genes in SIAC1 cells (Table 3).

Some tumor suppressor genes, including $M L H 1$, undergo CIMP epigenetic changes in a variety of cancers. ${ }^{13,22,35}$ It has also been reported that methylation of $M L H 1$ was a causative factor of MSI-H tumors in SBA and CRC. ${ }^{15,36}$ Thus, we examined epigenetic modification of MMR gene expression in SIAC1 cells treated with 5-aza-dc and trichostatin A. Western blot analysis indicated that neither agent increased MMR protein levels (Figure 1F). However, by qualitative PCR, MLH1 mRNA level was enhanced by 5-aza-dc alone and further in combination with trichostatin A (Figure 1G). Moreover, methylation-specific PCR assay showed that the $\mathrm{MLHI}$ promoter region was methylated in SIAC1 cells (Figure $1 \mathrm{H}$ ). These results suggest that MSI-H is caused by $M L H 1$ promoter methylation and a lack of MLH1 expression in SIAC1 cells.

Table 3 Frameshift Mutations in SIAC1 Cells

\begin{tabular}{lll}
\hline Target gene & Target site & SIAC1 genomic DNA \\
\hline FAS & $(\mathrm{T})_{7}$ & $(\mathrm{~T})_{7}$ \\
ACVR2 & $(\mathrm{A})_{8}$ & $(\mathrm{~A})_{7}$ \\
BAX & $(\mathrm{G})_{8}$ & $(\mathrm{G})_{7} /(\mathrm{G})_{8}$ \\
IGF2R & $(\mathrm{C})_{8}$ & $(\mathrm{C})_{8}$ \\
MSH3 & $(\mathrm{A})_{8}$ & $(\mathrm{~A})_{7} /(\mathrm{A})_{8}$ \\
MSH6 & $(\mathrm{C})_{8}$ & $(\mathrm{C})_{7}$ \\
NDUFC2 & $(\mathrm{T})_{9}$ & $(\mathrm{~T})_{9}$ \\
CASP5 & $(\mathrm{A})_{10}$ & $(\mathrm{~A})_{9} /(\mathrm{A})_{10}$ \\
TGFBR2 & $(\mathrm{A})_{10}$ & $(\mathrm{~A})_{9} /(\mathrm{A})_{10}$ \\
MARCKS & $(\mathrm{A})_{11}$ & $(\mathrm{~A})_{9} /(\mathrm{A})_{10} /(\mathrm{A})_{11}$ \\
\hline
\end{tabular}


Role of $\beta$-Catenin Mutation in SIAC1 Cells

Next, we examined mutation or aberrant expression of other proto-oncogenes and tumor suppressor genes reported to be involved in SBA, such as KRAS, BRAF, CTNNB1, APC, SMAD4, and TP53. ${ }^{15,21,37-39}$ DNA sequence analysis of genomic DNA of SIAC1 cells showed no mutations at codons 12 and 13 in $K R A S$, codon 600 in $B R A F$, mutation cluster region of $A P C$, and exons 18, 19, 21, and 23 in EGFR. Western blot analysis revealed a truncated form of $\beta$-catenin and decreased TGF $\beta R 2$ levels in SIAC1 cells, whereas SMAD4 and p53 levels were similar to those in Lovo and Hct1 16 cells, which have intact SMAD4 and p53 (Figure 2A). Aberrant p53 accumulation was not seen in SIAC1 cells.

Interstitial deletion of $C T N N B 1$ exon 3 is frequently found in SBA. ${ }^{40}$ Agarose gel electrophoresis of PCR products corresponding to CTNNB1 exons 1 to 6 using SIAC1 cell genomic DNA showed both a normal-sized band and a smaller band (Figure 2B). DNA sequencing revealed a 381-Bp inframe deletion spanning exons 3 to 4 , resulting in a mutant $\beta$-catenin protein that lacked amino acids 11 to 137 (Figure 2C). Since the deleted region of $\beta$-catenin included the degradation box, we examined the stability of this $\beta$-catenin mutant. We generated a $\beta$-catenin deletion (MUT) vector that lacked amino acids 11 to 137 of the WT $\beta$-catenin, and examined its stability after transfection into HEK293T cells. Treatment with a protein synthesis inhibitor, cycloheximide, decreased exogenous WT more rapidly than MUT $\beta$-catenin, indicating that the deletion mutant was more resistant to degradation (Figure 2D). We also evaluated the endogenous $\beta$-catenin protein in SIAC1 cells. The treatment of SIAC1 cells with cycloheximide decreased the amount of WT $\beta$-catenin in a time-dependent manner similar to that in HT29 cells (Figure 2E). In contrast, mutant $\beta$-catenin in SIAC1 cells was retained 12 hours after cycloheximide treatment, indicating that SIAC1 cells possess stable $\beta$-catenin protein.

Next, we investigated the function of mutant $\beta$-catenin in SIAC1 cells. A luciferase assay indicated that $\mathrm{Wnt} / \beta$-catenin signaling activity was significantly greater in SIAC1 cells than in RKO cells, which have normal Wnt/ $\beta$-catenin signaling
A

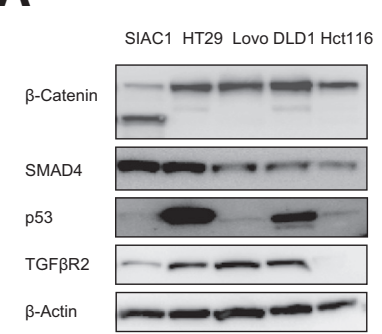

B

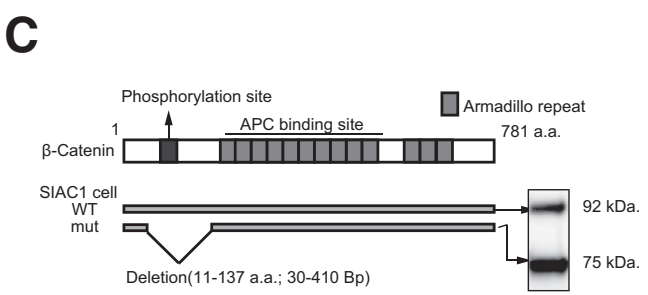

E

E

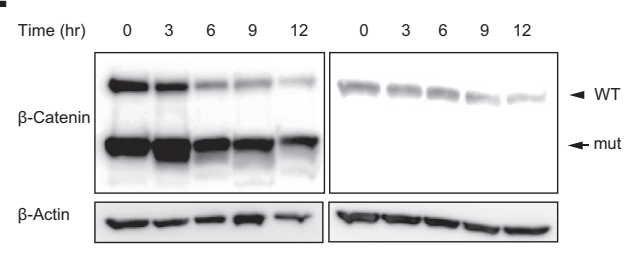

G
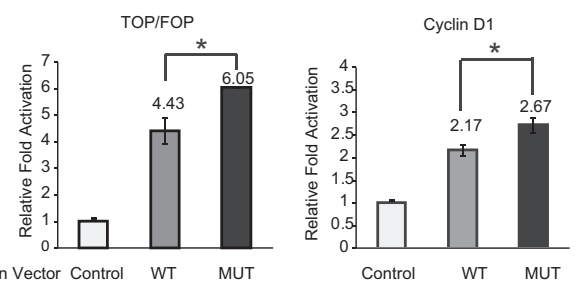
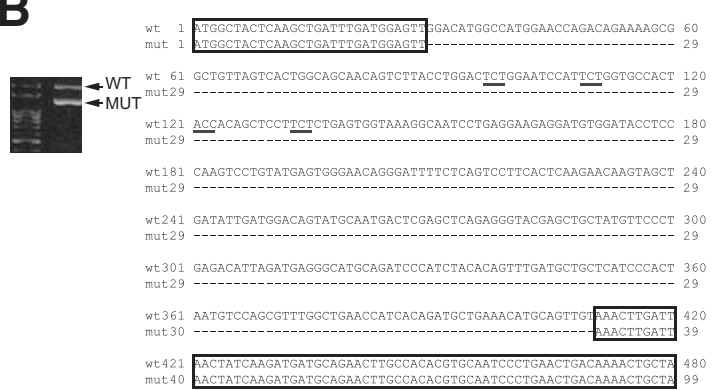

D

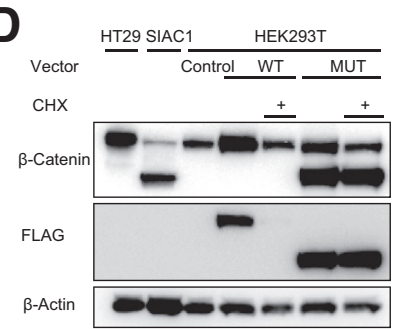

$\mathbf{F}$

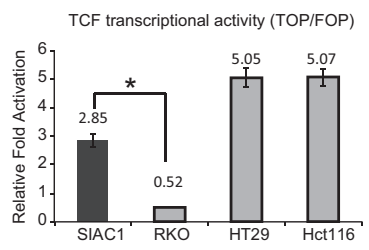

H

Figure $2 \beta$-Catenin deletion mutant in SIAC1 cells. A: SIAC1 cells and colorectal cancer cell lines were analyzed by Western blot analysis for $\beta$-catenin and tumor suppressor gene proteins. B: The $5^{\prime}$ region of $\beta$-catenin gene (CTNNB1) of SIAC1 was analyzed by PCR amplification and sequencing of the indicated PCR fragments. Normal- and smallersized fragments were noted as the wild type (WT) and deletion mutant (MUT), respectively. The sequences encoding the phosphorylation sites that function as a degradation targeting box are underlined. C: A schematic representation of $\beta$ catenin protein in SIAC1 cells. D: FLAG-tagged WT and deletion MUT $\beta$-catenin expressed in HEK293T cells were analyzed by Western blot analysis after treatment with $10 \mu \mathrm{g} / \mathrm{mL}$ cycloheximide (CHX). An anti-FLAG antibody was used to detect exogenous $\beta$-catenin. E: Endogenous $\beta$-catenin in SIAC1 and HT29 cells was analyzed by Western blot analysis after treatment with $\mathrm{CHX}$ at the indicated times. F: TCF transcriptional activities of SIAC1 and colorectal cancer cell lines. The activities in RKO, HT29, and Hct116 cells are shown as ratios of TOP/ FOP luciferase activity. G: TOP/FOP and cyclin D1 promoter activities were compared between WT and MUT $\beta$-catenin plasmid-transfected HEK293T cells. H: Photomicroscopy of SIAC1 organoids under culture condition with $[50 \mathrm{ng} / \mathrm{mL}$ of murine epidermal growth factor, $100 \mathrm{ng} / \mathrm{mL}$ of murine Noggin, human R-spondin-1 condition (ENR) medium; left] or without (EN medium; right) Rspondin-1 for 14 days. Data are expressed as means \pm SEM ( $\mathbf{F}$ and $\mathbf{G})$. ${ }^{*} P<0.05$. Scale bar $=100 \mu \mathrm{m}$. Original magnification, $\times 40(\mathbf{H})$. 
activity (Figure 2F). The function of the mutant $\beta$-catenin protein was also evaluated in an overexpression experiment. When transfected into HEK293T cells, MUT $\beta$-catenin exhibited increased $\mathrm{Wnt} / \beta$-catenin signaling activity compared with the WT vector (Figure 2G). Moreover, the MUT vector stimulated transcriptional activity of the cyclin D1 promoter, which is a known oncogene and one of the target genes of Wnt/ $\beta$-catenin signaling (Figure $2 \mathrm{G}$ ). Interestingly, we also found that, like CRC cells, SIAC1 cells formed organoids in 3D culture without R-spondin-1, which is an agonist of the canonical Wnt/ $\beta$-catenin signaling and is essential for the organoid formation from normal crypt (Figure $2 \mathrm{H}$ ). ${ }^{26,33}$ These results indicate that the deletion of exon 3 of CTNNB1 is a carcinogenic factor in SIAC1 cells through aberrant activation of intracellular $\mathrm{Wnt} / \beta$-catenin signaling.

\section{Comparison with Clinical SBA Specimens}

We compared the molecular characteristics of SIAC1 cells to those of clinical SBA samples. The SBA patient tumor characteristics are summarized in Table 4. We used 10 SBA samples for comparison, excluding the tumor from sample 1, which was the origin of the SIAC1 cell line. One case (sample 9) was considered to have familial adenomatous polyposis as a predisposing disease, based on the patient's family history.

MMR expression was evaluated by IHC analysis. MLH1, $\mathrm{MSH} 2$, and MSH6 proteins were localized in the nucleus of the glands and lymphoid cells of normal small bowel tissue. IHC analysis demonstrated that MLH1, MSH2, or MSH6 expression was lost or weak in three cases (30\%), one case $(10 \%)$, and two cases (20\%), respectively, and that four cases $(40 \%)$ had lost expression of at least one MMR protein (Figure 3A and Table 4).

Subsequently, genomic DNA extracted from SBA specimens was analyzed for mutations of MSI target genes. Heterozygous frameshift mutations of CASP5, TGFBR2, and $M A R C K S$ were found in all samples (Table 4). In contrast, no frameshift mutations in $I G F 2 R$ were present in any samples. Frameshift mutations in the other MSI target genes, $B A X$, $M S H 3$, and MSH6, were found in one tissue (10\%), two tissues (20\%), and three tissues (30\%), respectively. We also investigated the mutation of proto-oncogenes reported in SBA, that is, KRAS and BRAF. ${ }^{14,15,41}$ Mutation at codon 12 or 13 in the KRAS gene was present in three cases (30\%), whereas mutation at codon 600 in $B R A F$ was not detected in any clinical SBA samples (Table 4).

Since we found significant abnormalities in CTNNB1 in SIAC 1 cells, we examined the $\beta$-catenin status in clinical SBA tissues. It has been reported that WT $\beta$-catenin protein localizes along the intercellular borders of normal small bowel mucosa; however, the interstitial deletion mutant of exon 3 exhibits altered localizations to the nucleus and cytoplasm. $^{38,40}$ IHC analysis for $\beta$-catenin localization revealed a cytoplasmic pattern in two cases $(20 \%)$, and that one case $(10 \%)$ was nuclear and cytoplasmic, rather than membranous (Figure 3B and Table 2). PCR of genomic DNA showed deletion mutants in two cases (20\%). Samples 3 and 10 had interstitial deletion of CTNNBI at Bps 44 to 430 and 29 to 251 (+1 Bp insertion), respectively. These results indicate that SIAC1 cells have many molecular characteristics found in clinical SBA specimens, suggesting this cell line to be a promising in vitro model of SBA.

Table 4 Results of Sequence Analysis and IHC Analysis of the SBA Samples

\begin{tabular}{|c|c|c|c|c|c|c|c|c|c|c|c|}
\hline Sample no. & $1^{*}$ & 2 & 3 & 4 & 5 & 6 & 7 & 8 & 9 & 10 & 11 \\
\hline $\begin{array}{l}\text { Location } \\
\text { Pathology }\end{array}$ & $\begin{array}{l}\text { Jejunum } \\
\text { tub1 }>\text { por }\end{array}$ & $\begin{array}{l}\text { Jejunum } \\
\text { tub1 }\end{array}$ & $\begin{array}{l}\text { Jejunum } \\
\text { tub1 }\end{array}$ & $\begin{array}{l}\text { Ileum } \\
\text { tub2 }\end{array}$ & $\begin{array}{l}\text { Jejunum } \\
\text { tub1 }>\text { pap }\end{array}$ & $\begin{array}{l}\text { Duodenum } \\
\text { tub1 }>2\end{array}$ & $\begin{array}{l}\text { Duodenum } \\
\text { pap }>\text { tub1 }\end{array}$ & $\begin{array}{l}\text { Duodenum } \\
\text { por }\end{array}$ & $\begin{array}{l}\text { Jejunum } \\
\text { tub1 }>2\end{array}$ & $\begin{array}{l}\text { Ileum } \\
\text { tub1 }\end{array}$ & $\begin{array}{l}\text { Ileum } \\
\text { tub1,2 }\end{array}$ \\
\hline Stage & III & IV & III & IV & $\mathrm{I}$ & II & II & IV & IV & IV & II \\
\hline MLH1 IHC & Lost & Lost & Lost & & & & & Lost & & & \\
\hline MSH2 IHC & Weak & & & & & & & Lost & & & \\
\hline MSH6 IHC & Lost & Lost & & & & & & & Lost & & \\
\hline$B R A F$ mutation & WT & WT & WT & WT & WT & WT & WT & WT & WT & WT & WT \\
\hline CTNNB1 (Bp) & $\begin{array}{l}\text { Del. } \\
\qquad(30-410)\end{array}$ & WT & $\begin{array}{l}\text { Del. } \\
\qquad(44-430)\end{array}$ & WT & WT & WT & WT & WT & WT & $\begin{array}{l}\text { Del. }+1 \\
\quad(29-251)\end{array}$ & ND \\
\hline ACVR2 (A)8 & $(A)_{7 / 8}$ & WT & WT & WT & WT & WT & WT & WT & WT & WT & WT \\
\hline$B A X(C) 8$ & $(C)_{7 / 8}$ & $(\mathrm{C})_{7 / 8 / 9}$ & WT & WT & WT & WT & WT & WT & WT & WT & WT \\
\hline TGFBR2 (T)10 & $(T)_{9 / 10}$ & $(\mathrm{~T})_{9 / 10}$ & $(T)_{9 / 10}$ & $(T)_{9 / 10}$ & $(T)_{9 / 10}$ & $(T)_{9 / 10}$ & $(T)_{9 / 10}$ & $(T)_{9 / 10}$ & $(T)_{9 / 10}$ & $(T)_{9 / 10}$ & $(T)_{9 / 10}$ \\
\hline MARCKS (A)11 & $(\mathrm{A})_{9 / 10 / 11}$ & $(A)_{10 / 11}$ & $(\mathrm{~A})_{9 / 10 / 11}$ & $(\mathrm{~A})_{10 / 11}$ & $(A)_{10 / 11}$ & $(\mathrm{~A})_{10 / 11}$ & $(A)_{10 / 11}$ & $(\mathrm{~A})_{9 / 10 / 11}$ & $(\mathrm{~A})_{10 / 11}$ & $(A)_{10 / 11}$ & $(\mathrm{~A})_{10 / 11}$ \\
\hline
\end{tabular}

Blank spaces indicate normal expression of MMR genes.

*Sample 1 was original tissue from the SIAC1 cell line and was excluded from the comparative analysis of clinical SBA specimens.

C, cytoplasmic localization; IHC, immunohistochemical analysis; M, cell membranous localization; N, nuclear localization; ND, not determined; SBA, small bowel adenocarcinoma; WT, wild type. 
A
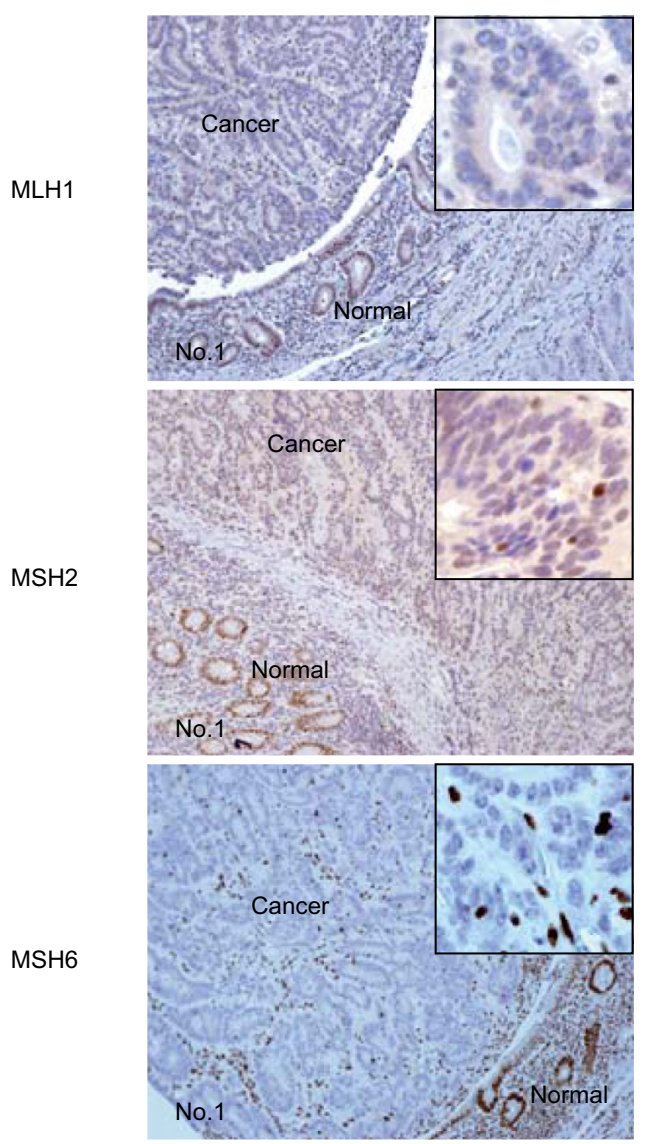

Positive
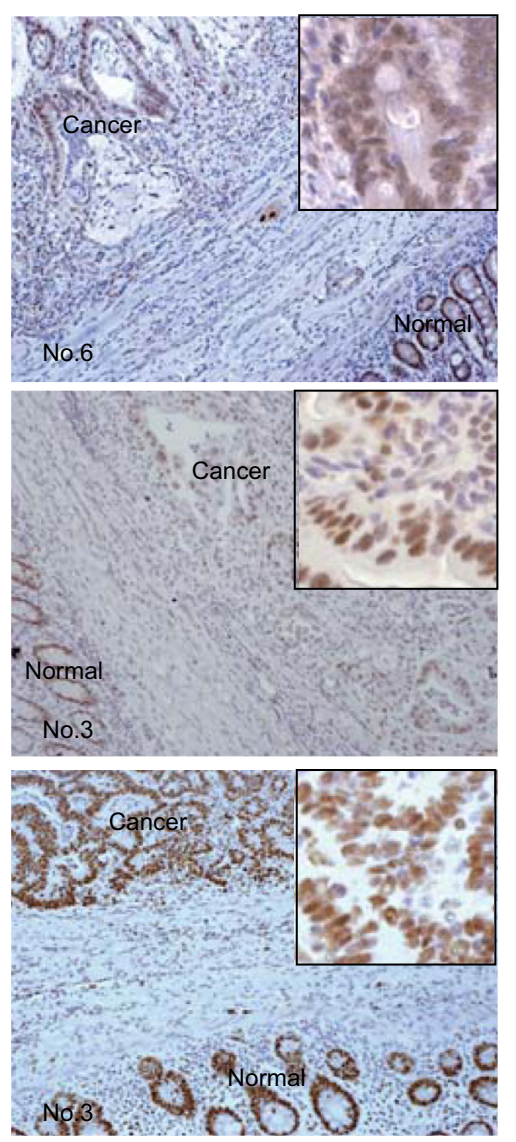

Figure 3 Immunohistochemistry analysis of clinical small bowel adenocarcinoma (SBA) tissues. A: Immunohistochemical staining for MLH1, MSH2, and MSH6 proteins was performed with SBA samples. The staining is lost for MLH1, MSH2, and MSH6 in the cancerous lesions of sample 1 . Positive staining is observed for the indicated mismatch repair (MMR) protein. Insets show high-magnification images of the cancerous lesions. B: $\beta$-Catenin staining is found along the cellular membrane of normal mucosa and cancers with intact $\beta$-catenin. Aberrant expression of $\beta$-catenin is indicated by decreased membranous staining and accumulation in the cytoplasm and nucleus. Insets show high-magnification image (upper right) and with hematoxylin and eosin staining (lower right) of the cancerous lesions. Original magnification: $\times 100$ (main images, $A$ and $B$ ); $\times 200$ (insets, A); $\times 400$ (insets, B).

B

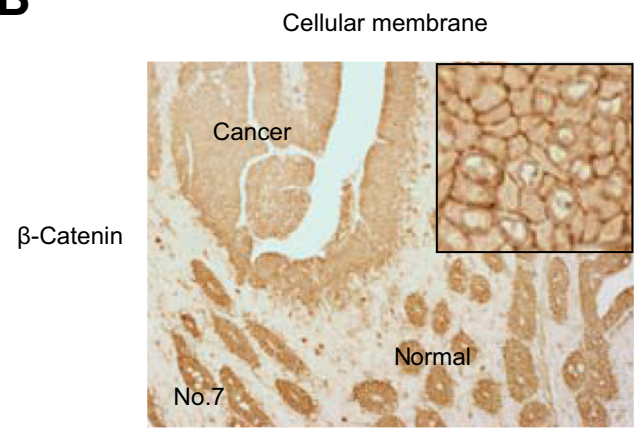

MSH6

B

Screening and Mechanistic Analysis of Anti-Cancer Drugs for SBA Treatment Using SIAC1 Cells

Since a specific or molecular-targeted therapy against SBA has not been established, we assessed the effect of 140 anti-cancer drugs on the death of SIAC1 cells. These drugs included molecular-targeted drugs commonly used for the treatment of gastric cancer and CRC, such as vascular endothelial growth factor, epidermal growth factor receptor, and human epidermal growth factor receptor 2 inhibitors. The results of the first drug screening are shown in Figure 4A and Supplemental Table S2. Twenty-five drugs, including AKT inhibitors, platelet-derived growth factor receptor inhibitors, and epidermal growth factor receptor inhibitors such

\section{Cytoplasm}

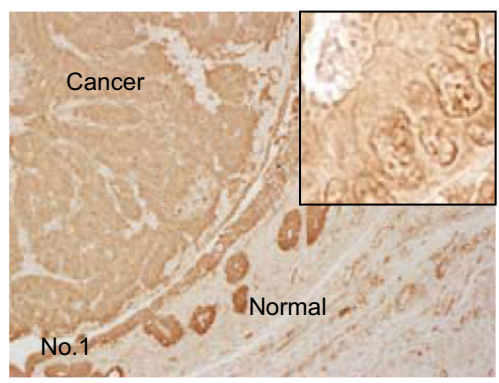

Nucleus + cytoplasm

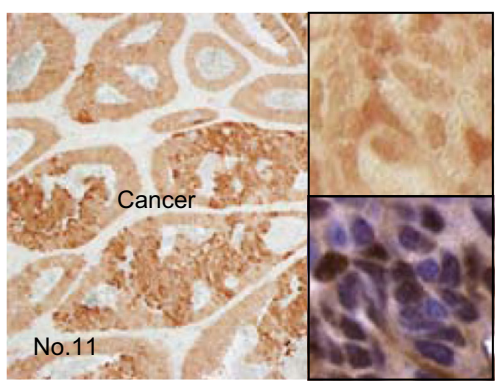

as gefitinib and erlotinib, inhibited SIAC1 cell growth by $50 \%$ at $10 \mu \mathrm{mol} / \mathrm{L}$ for 96 hours.

These 25 drugs were used in a second screening experiment at concentrations of $1,0.1$, and $0.01 \mu \mathrm{mol} / \mathrm{L}$. The protease inhibitor bortezomib and the tubulin and microtubule inhibitor eribulin showed efficacy at an optimal concentration of $0.01 \mu \mathrm{mol} / \mathrm{L}$ (Figure 4B). In this second screening, moleculartargeted drugs against digestive malignancies, such as bevacizumab, cetuximab, trastuzumab, and erlotinib, were also examined but were not effective against SIAC1 cells.

To assess the effects of bortezomib and eribulin against SIAC1 cells, we examined the activity of $\mathrm{Wnt} / \beta$-catenin signaling. Eribulin, but not bortezomib, decreased $\mathrm{Wnt} / \beta$ catenin signaling (Figure $4 \mathrm{C}$ ). The expression levels of its 

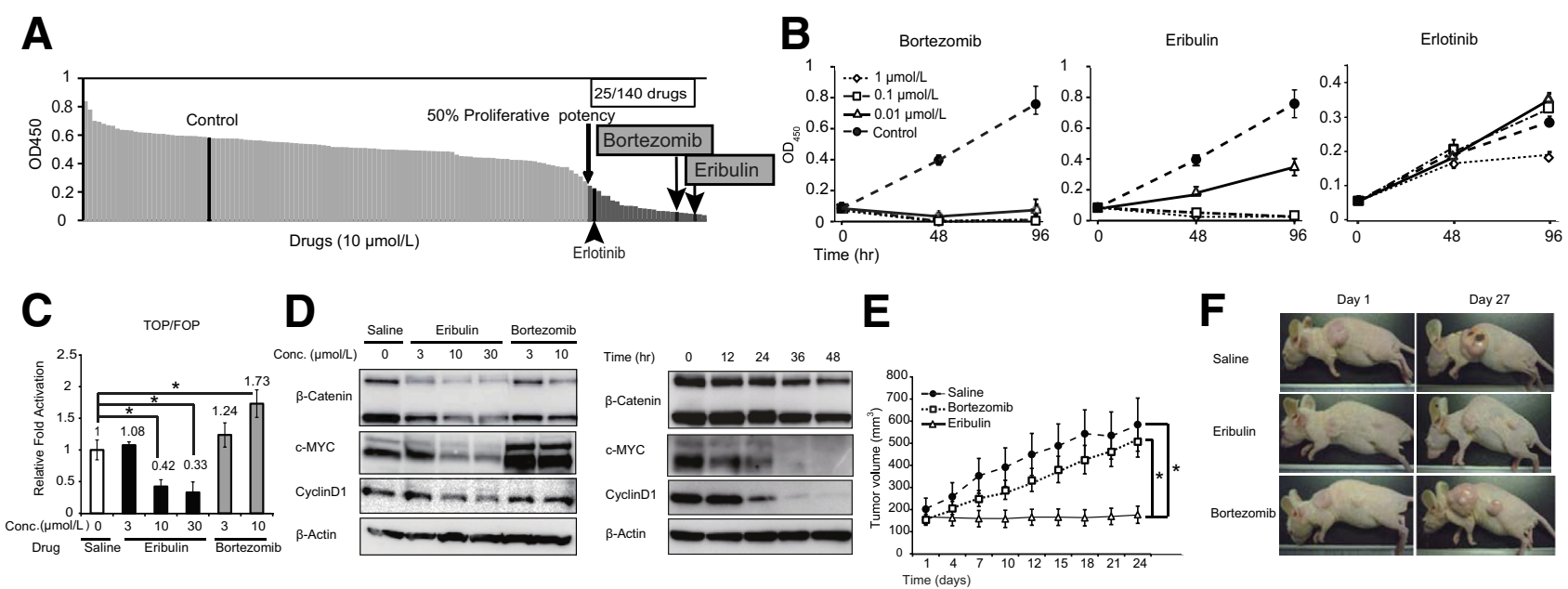

G
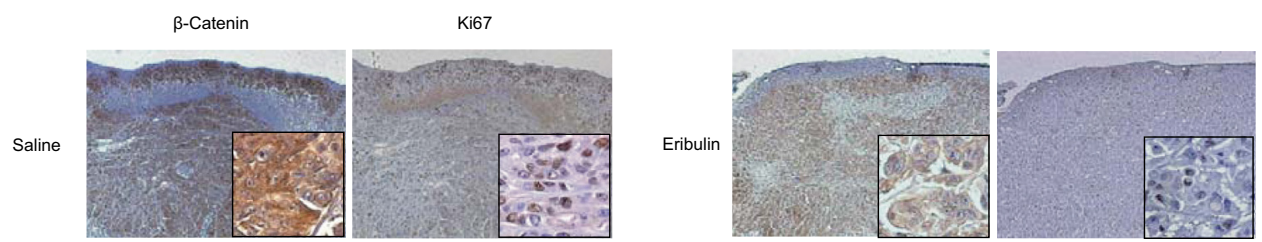

Figure 4 Drug screening for small bowel adenocarcinoma (SBA) treatment using SIAC1 cells. A: Waterfall plot showing the results of screening of 140 anticancer drugs. Dimethyl sulfoxide was administered as a control, and evaluation was performed 96 hours after treatment. B: Proliferation of SIAC1 cells was evaluated using a dilution series of bortezomib, eribulin, and erlotinib. Optical density at $450 \mathrm{~nm}$ was measured at 0, 48 , and 96 hours after the administration of the anticancer drugs at the indicated concentrations. C: Effect of eribulin and bortezomib on Wnt/ $\beta$-catenin signaling was analyzed by luciferase assay. Evaluation was performed by calculating the relative ratio of TOP/FOP to saline. D: SIAC1 cells were analyzed by Western blot analysis for $\beta$-catenin, c-Myc, and cyclin D1 proteins after treatment with the indicated concentrations of bortezomib and eribulin for 24 hours (right) or with $100 \mu \mathrm{mol} / \mathrm{L}$ eribulin for the indicated times (left). E: Nude mice with s.c. SIAC1 tumors were dosed with bortezomib (white square), eribulin (triangle), or saline (circle), and the volumes of the tumors were measured. F: Images on days 1 and 27 of mouse xenografts treated with saline, bortezomib, and eribulin. G: Immunohistochemical staining for $\beta$-catenin and Ki67 was performed with SIAC1 xenograft tumors treated with saline or eribulin. Inset shows a high magnification image of the cancerous lesion. Data are expressed as means \pm SD (B), means \pm SEM (C and E). ${ }^{*} P<0.05$. Original magnification: $\times 40(\mathbf{G}$, main image); $\times 400(\mathbf{G}$, inset)

downstream targets, c-MYC and cyclin D1, were decreased by eribulin treatment in a dose- and time-dependent manner (Figure 4D). Interestingly, eribulin treatment significantly decreased WT and mutant $\beta$-catenin protein levels in SIAC1 cells (Figure $4 \mathrm{D}$ ), suggesting that eribulin affects $\beta$-catenin stability.

Finally, we used a SIAC1 xenograft mouse model to validate the efficacy of bortezomib and eribulin in SBA in vivo. Treatment with eribulin significantly inhibited tumor growth compared with saline $\left(177 \pm 39 \mathrm{~mm}^{3}\right.$ versus $\left.575 \pm 120 \mathrm{~mm}^{3} ; P=0.01\right)$; however, bortezomib did not decrease the tumor volume (Figure 4, E and F). Immunostaining of xenograft tumors for $\beta$-catenin supported the results of the in vitro eribulin treatment experiment (Figure 4G). Ki-67-positive cells were also decreased in tumors treated with eribulin (Figure $4 G$ ). These results suggest eribulin to be an effective drug for the treatment of SBA.

\section{Discussion}

In this study we established an SBA cell line termed SIAC1 and used it to unravel the molecular abnormalities associated with, and to identify a treatment of, SBA. To our knowledge, this is the first report of a cell line derived from
SBA, which will increase our understanding of this rare malignancy. The established SIAC1 cell line was successfully cultured in a plastic dish, as well as in a 3D culture condition, resulting in organoid formation, and on the s.c. tissue of nude mice. The merit of establishing a cell line is the supply of stable experimental material, which enables detailed characteristic analysis, functional assays, and drug screening. A comparison of SIAC1 cells to clinical SBA samples showed molecular similarities, indicating that this cell line is representative of SBA in several important respects.

Recent studies of cancer genetics have indicated that three major events, that is, chromosomal instability, MSI, and CIMP, were closely associated with gastrointestinal carcinogenesis. ${ }^{13-15}$ In CRC development, these molecular disorders represent distinct carcinogenic pathways. ${ }^{14}$ However, in SBA, the contribution of these events is relatively unknown. ${ }^{15}$ In our analysis, the expression of several MMR genes was lost in some SBA specimens, including in SIAC1 cells. The analysis of microsatellite markers revealed that SIAC1 cells are MSI-H. Previous reports of MSI-H SBA showed a high frequency of frameshift mutations in target genes such as TGFBR2, CASP5, and MARCKS, ${ }^{18}$ which our data confirmed in SIAC1 cells and SBA specimens. Interestingly, we found that all SBA specimens had heterogeneous 
mutations of target genes, which resulted in $>10$ repeats. In colorectal and gastric cancers, MLH1 expression is frequently suppressed by CIMP. ${ }^{23,36,42}$ We found that 5 -aza-dc treatment significantly increased MLH1 mRNA levels (Figure 1G), and methylated modification of $M L H 1$ promoter region was found in SIAC1 cells (Figure 1H). However, the MLH1 protein levels were not restored by treatment with 5-aza-dc alone or in combination with trichostatin A (Figure 1F). This result suggests the contribution of other mechanisms of regulation of MLH1 protein synthesis, such as post-transcriptional modifications or microRNAs. ${ }^{43,44}$

We also examined the status of oncogenes and tumor suppressor genes in SBA. We found no mutations in BRAF in our clinical SBA specimens, which are frequently observed in CIMP, although three tumors showed a loss of MLH1 protein. The rarity of BRAF mutations in SBA was similar to that in previous reports. ${ }^{15,45,46}$ Thus, the contribution of CIMP and MLH1 suppression may be different in SBA compared with the transition from serrated adenoma to CRC. ${ }^{14}$

One of the important findings of this study is that SIAC1 cells had a mono-allelic in-frame deletion of CTNNB1 spanning exons 3 to 4 , as reported previously. ${ }^{40}$ Exon 3 of CTNNB1 contains a degradation box. Deletion of this site stabilizes $\beta$-catenin, resulting in abnormal activation of Wnt/ $\beta$-catenin signaling and downstream targets, such as c-MYC and cyclin $\mathrm{D} 1,{ }^{47}$ which leads to large and small intestinal carcinogenesis. ${ }^{40}$ Thus, in SIAC1 cells, the amount of mutant $\beta$-catenin protein was greater than that of WT $\beta$-catenin (Figure 2A). Moreover, mutant $\beta$-catenin was more resistant to degradation (Figure $2 \mathrm{E}$ ), which elevated $\mathrm{Wnt} / \beta$-catenin signaling activity compared with that in RKO cells (Figure 2F). The formation of SIAC1 organoids without $\mathrm{R}$-spondin-1 suggests that mutant $\beta$-catenin functionally complements the activity of $\mathrm{Wnt} / \beta$-catenin signaling. The crucial role of $\mathrm{Wnt} / \beta$-catenin and transforming growth factor $\beta$ signaling in invasive tumor formation in the small intestine was reported in a genetically engineered mouse model. ${ }^{48}$ Thus, we considered that aberrant $\beta$-catenin accumulation due to mutation, coupled with dysregulated transforming growth factor $\beta$ signaling by MSI, contribute to the development of human SBA.

Another novel finding of this study comes from the drug screening. We tested $>100$ drugs with known target molecules and found that 2 drugs inhibited the growth of SIAC1 cells under optimal conditions. One of the candidate drugs was a proteasome inhibitor, bortezomib, which is an established agent for the treatment of multiple myeloma. ${ }^{49}$ In vitro experiments showed that bortezomib has cytotoxic effects against multiple tumors, including gastric cancer. ${ }^{30}$ Unfortunately, a xenograft experiment using SIAC1 cells failed to verify its anti-cancer efficacy. Thus, it is necessary to test additional cell lines to verify the therapeutic effect of bortezomib against SBA.

Eribulin is an anti-cancer agent used for breast cancer treatment. It is a synthetic analogue of halichondrin B, which is extracted from a variety of sponges, including
Halichondria okadai. ${ }^{50}$ The activity of eribulin is based on a tubulin-based antimitotic mechanism similar to that of a Vinca alkaloid. ${ }^{51}$ We found that eribulin inhibited SIAC1 cell growth and xenograft tumor growth via suppressed Wnt $/ \beta$ catenin signaling. Western blot analysis showed accelerated degradation of $\beta$-catenin protein after treatment with eribulin and subsequent decreases in c-MYC and cyclin D1 protein levels. Importantly, the mutant $\beta$-catenin protein level in SIAC1 cells also decreased, suggesting that eribulin affects $\beta$-catenin stabilization independently of its degradation box, which is encoded by exon 3 . The stability and degradation of $\beta$-catenin are regulated by several kinases at multiple phosphorylation sites. ${ }^{52}$ Eribulin may affect the degradation mechanism independently of GSK3 $\beta$, AXIN, APC, and CK1 complex. Among the drugs screened, three Wnt inhibitors did not inhibit the growth of SIAC1 cells. Thus, targeting $\beta$-catenin by eribulin may be useful in the treatment of SBA.

In summary, we established an SBA cell line and found MSI and $\beta$-catenin mutations to be molecular characteristics of SBA. Furthermore, eribulin exerted an anti-cancer effect both in vitro and in vivo, suggesting its potential as a therapy for SBA.

\section{Acknowledgments}

We thank the Screening Committee of Anti-Cancer Drugs for gift of the inhibitor kits. RSpo1-Fc HEK293T cells were provided by Toshiro Sato (Keio University, Tokyo, Japan) with permission from Calvin Kuo (Stanford University, Palo Alto, CA).

\section{Supplemental Data}

Supplemental material for this article can be found at http://dx.doi.org/10.1016/j.ajpath.2014.10.006.

\section{References}

1. Bilimoria KY, Bentrem DJ, Wayne JD, Ko CY, Bennett CL, Talamonti MS: Small bowel cancer in the United States: changes in epidemiology, treatment, and survival over the last 20 years. Ann Surg 2009, 249:63-71

2. Suzuki H, Yamada A, Watabe H, Kobayashi Y, Hirata Y, Yamaji Y, Yoshida H, Koike K: Successful treatment of early-stage jejunum adenocarcinoma by endoscopic mucosal resection using double-balloon endoscopy: a case report. Diagn Ther Endosc 2012, 2012:521960

3. Iddan G, Meron G, Glukhovsky A, Swain P: Wireless capsule endoscopy. Nature 2000, 405:417

4. Yamamoto H, Sekine Y, Sato Y, Higashizawa T, Miyata T, Iino S, Ido K, Sugano K: Total enteroscopy with a nonsurgical steerable double-balloon method. Gastrointest Endosc 2001, 53: 216-220

5. Benson AB 3rd, Bekaii-Saab T, Chan E, Chen YJ, Choti MA Cooper HS, Engstrom PF, Enzinger PC, Fakih MG, Fenton MJ, Fuchs CS, Grem JL, Hunt S, Kamel A, Leong LA, Lin E, May KS, Mulcahy MF, Murphy K, Rohren E, Ryan DP, Saltz L, Sharma S, Shibata D, Skibber JM, Small W Jr, Sofocleous CT, Venook AP, Willett CG, Gregory KM, Freedman-Cass DA: Metastatic colon 
cancer, version 3.2013: featured updates to the NCCN Guidelines. J Natl Compr Canc Netw 2013, 11:141-152

6. Wu AH, Yu MC, Mack TM: Smoking, alcohol use, dietary factors and risk of small intestinal adenocarcinoma. Int J Cancer 1997, 70:512-517

7. Delaunoit T, Neczyporenko F, Limburg PJ, Erlichman C: Pathogenesis and risk factors of small bowel adenocarcinoma: a colorectal cancer sibling? Am J Gastroenterol 2005, 100:703-710

8. Vogelstein B, Fearon ER, Hamilton SR, Kern SE, Preisinger AC, Leppert M, Nakamura Y, White R, Smits AM, Bos JL: Genetic alterations during colorectal-tumor development. N Engl J Med 1988, 319:525-532

9. Sellner F: Investigations on the significance of the adenomacarcinoma sequence in the small bowel. Cancer 1990, 66:702-715

10. Rim SH, Seeff L, Ahmed F, King JB, Coughlin SS: Colorectal cancer incidence in the United States, 1999-2004: an updated analysis of data from the National Program of Cancer Registries and the Surveillance, Epidemiology, and End Results Program. Cancer 2009, 115:1967-1976

11. Talamonti MS, Goetz LH, Rao S, Joehl RJ: Primary cancers of the small bowel: analysis of prognostic factors and results of surgical management. Arch Surg 2002, 137:564-570. discussion 570-571

12. O'Connell JB, Maggard MA, Ko CY: Colon cancer survival rates with the new American Joint Committee on Cancer sixth edition staging. J Natl Cancer Inst 2004, 96:1420-1425

13. Boland CR: The molecular biology of gastrointestinal cancer: implications for diagnosis and therapy. Gastrointest Endosc Clin N Am 2008, 18:401-413. vii

14. Issa JP: Colon cancer: it's CIN or CIMP. Clin Cancer Res 2008, 14 5939-5940

15. Warth A, Kloor M, Schirmacher P, Bläker H: Genetics and epigenetics of small bowel adenocarcinoma: the interactions of CIN, MSI, and CIMP. Mod Pathol 2011, 24:564-570

16. Olschwang S: Germline mutation and genome instability. Eur J Cancer Prev 1999, 8(Suppl 1):S33-S37

17. Pinheiro M, Ahlquist T, Danielsen SA, Lind GE, Veiga I, Pinto C, Costa V, Afonso L, Sousa O, Fragoso M, Santos L, Henrique R, Lopes P, Lopes C, Lothe RA, Teixeira MR: Colorectal carcinomas with microsatellite instability display a different pattern of target gene mutations according to large bowel site of origin. BMC Cancer 2010, 10:587

18. Michel S, Kloor M, Singh S, Gdynia G, Roth W, von Knebel Doeberitz M, Schirmacher P, Bläker H: Coding microsatellite instability analysis in microsatellite unstable small intestinal adenocarcinomas identifies MARCKS as a common target of inactivation. Mol Carcinog 2010, 49:175-182

19. Laforest A, Aparicio T, Zaanan A, Silva FP, Didelot A, Desbeaux A, Le Corre D, Benhaim L, Pallier K, Aust D, Pistorius S, Blons H, Svrcek M, Laurent-Puig P: ERBB2 gene as a potential therapeutic target in small bowel adenocarcinoma. Eur J Cancer 2014, 50:1740-1746

20. Hibi K, Kondo K, Akiyama S, Ito K, Takagi H: Frequent genetic instability in small intestinal carcinomas. Jpn J Cancer Res 1995, 86:357-360

21. Overman MJ, Pozadzides J, Kopetz S, Wen S, Abbruzzese JL, Wolff RA, Wang H: Immunophenotype and molecular characterisation of adenocarcinoma of the small intestine. Br J Cancer 2010, 102:144-150

22. Herman JG: Hypermethylation of tumor suppressor genes in cancer. Semin Cancer Biol 1999, 9:359-367

23. Toyota M, Ahuja N, Ohe-Toyota M, Herman JG, Baylin SB, Issa JP: $\mathrm{CpG}$ island methylator phenotype in colorectal cancer. Proc Natl Acad Sci U S A 1999, 96:8681-8686

24. Konishi K, Watanabe Y, Shen L, Guo Y, Castoro RJ, Kondo K, Chung W, Ahmed S, Jelinek J, Boumber YA, Estecio MR, Maegawa S, Kondo Y, Itoh F, Imawari M, Hamilton SR, Issa JP: DNA methylation profiles of primary colorectal carcinoma and matched liver metastasis. PLoS One 2011, 6:e27889

25. Ootani A, Li X, Sangiorgi E, Ho QT, Ueno H, Toda S, Sugihara H, Fujimoto K, Weissman IL, Capecchi MR, Kuo CJ: Sustained in vitro intestinal epithelial culture within a Wnt-dependent stem cell niche. Nat Med 2009, 15:701-706

26. Sato T, Vries RG, Snippert HJ, van de Wetering M, Barker N, Stange DE, van Es JH, Abo A, Kujala P, Peters PJ, Clevers H: Single
Lgr5 stem cells build crypt-villus structures in vitro without a mesenchymal niche. Nature 2009, 459:262-265

27. Sakitani K, Hirata Y, Hayakawa Y, Serizawa T, Nakata W, Takahashi R, Kinoshita H, Sakamoto K, Nakagawa H, Akanuma M, Yoshida H, Maeda S, Koike K: Role of interleukin-32 in Helicobacter pyloriinduced gastric inflammation. Infect Immun 2012, 80:3795-3803

28. Boland CR, Goel A: Microsatellite instability in colorectal cancer. Gastroenterology 2010, 138:2073-2087.e3

29. Dietmaier W, Wallinger S, Bocker T, Kullmann F, Fishel R, Rüschoff J: Diagnostic microsatellite instability: definition and correlation with mismatch repair protein expression. Cancer Res 1997, 57:4749-4756

30. Nakata W, Hayakawa Y, Nakagawa H, Sakamoto K, Kinoshita H, Takahashi R, Hirata Y, Maeda S, Koike K: Anti-tumor activity of the proteasome inhibitor bortezomib in gastric cancer. Int J Oncol 2011, 39:1529-1536

31. Williams S, Pettaway C, Song R, Papandreou C, Logothetis C, McConkey DJ: Differential effects of the proteasome inhibitor bortezomib on apoptosis and angiogenesis in human prostate tumor xenografts. Mol Cancer Ther 2003, 2:835-843

32. Fornier M, Fumoleau P: The paradox of triple negative breast cancer: novel approaches to treatment. Breast J 2012, 18:41-51

33. Sato T, Stange DE, Ferrante M, Vries RG, Van Es JH, Van den Brink S, Van Houdt WJ, Pronk A, Van Gorp J, Siersema PD, Clevers H: Long-term expansion of epithelial organoids from human colon, adenoma, adenocarcinoma, and Barrett's epithelium. Gastroenterology 2011, 141:1762-1772

34. Duldulao MP, Lee W, Le M, Chen Z, Li W, Wang J, Gao H, Li H, Kim J, Garcia-Aguilar J: Gene expression variations in microsatellite stable and unstable colon cancer cells. J Surg Res 2012, 174:1-6

35. Teodoridis JM, Hardie C, Brown R: CpG island methylator phenotype (CIMP) in cancer: causes and implications. Cancer Lett 2008, 268: $177-186$

36. Vlaykova T, Mitkova A, Stancheva G, Kadiyska T, Gulubova M, Yovchev Y, Cirovski G, Chilingirov P, Damyanov D, Kremensky I, Mitev V, Kaneva R: Microsatellite instability and promoter hypermethylation of MLH1 and MSH2 in patients with sporadic colorectal cancer. J BUON 2011, 16:265-273

37. Arai M, Shimizu S, Imai Y, Nakatsuru Y, Oda H, Oohara T, Ishikawa T: Mutations of the Ki-ras, p53 and APC genes in adenocarcinomas of the human small intestine. Int J Cancer 1997, 70:390-395

38. Wheeler JM, Warren BF, Mortensen NJ, Kim HC, Biddolph SC, Elia G, Beck NE, Williams GT, Shepherd NA, Bateman AC, Bodmer WF: An insight into the genetic pathway of adenocarcinoma of the small intestine. Gut 2002, 50:218-223

39. Bläker H, Aulmann S, Helmchen B, Otto HF, Rieker RJ, Penzel R: Loss of SMAD4 function in small intestinal adenocarcinomas: comparison of genetic and immunohistochemical findings. Pathol Res Pract 2004, 200:1-7

40. Breuhahn K, Singh S, Schirmacher P, Bläker H: Large-scale N-terminal deletions but not point mutations stabilize beta-catenin in small bowel carcinomas, suggesting divergent molecular pathways of small and large intestinal carcinogenesis. J Pathol 2008, 215:300-307

41. Weisenberger DJ, Siegmund KD, Campan M, Young J, Long TI, Faasse MA, Kang GH, Widschwendter M, Weener D, Buchanan D, Koh H, Simms L, Barker M, Leggett B, Levine J, Kim M, French AJ, Thibodeau SN, Jass J, Haile R, Laird PW: CpG island methylator phenotype underlies sporadic microsatellite instability and is tightly associated with BRAF mutation in colorectal cancer. Nat Genet 2006, 38:787-793

42. Fleisher AS, Esteller M, Tamura G, Rashid A, Stine OC, Yin J, Zou TT, Abraham JM, Kong D, Nishizuka S, James SP, Wilson KT, Herman JG, Meltzer SJ: Hypermethylation of the hMLH1 gene promoter is associated with microsatellite instability in early human gastric neoplasia. Oncogene 2001, 20:329-335

43. Schetter AJ, Leung SY, Sohn JJ, Zanetti KA, Bowman ED, Yanaihara N, Yuen ST, Chan TL, Kwong DL, Au GK, Liu CG, Calin GA, Croce CM, Harris CC: MicroRNA expression profiles 
associated with prognosis and therapeutic outcome in colon adenocarcinoma. JAMA 2008, 299:425-436

44. Vogt M, Munding J, Grüner M, Liffers ST, Verdoodt B, Hauk J, Steinstraesser L, Tannapfel A, Hermeking H: Frequent concomitant inactivation of miR-34a and miR-34b/c by $\mathrm{CpG}$ methylation in colorectal, pancreatic, mammary, ovarian, urothelial, and renal cell carcinomas and soft tissue sarcomas. Virchows Arch 2011, 458: 313-322

45. Zaanan A, Costes L, Gauthier M, Malka D, Locher C, Mitry E, Tougeron D, Lecomte T, Gornet JM, Sobhani I, Moulin V, Afchain P, Taïeb J, Bonnetain F, Aparicio T: Chemotherapy of advanced smallbowel adenocarcinoma: a multicenter AGEO study. Ann Oncol 2010, 21:1786-1793

46. Aparicio T, Svrcek M, Zaanan A, Beohou E, Laforest A, Afchain P, Mitry E, Taieb J, Di Fiore F, Gornet JM, Thirot-Bidault A, Sobhani I, Malka D, Lecomte T, Locher C, Bonnetain F, Laurent-Puig P: Small bowel adenocarcinoma phenotyping, a clinicobiological prognostic study. Br J Cancer 2013, 109:3057-3066
47. Li YJ, Wei ZM, Meng YX, Ji XR: Beta-catenin up-regulates the expression of cyclinD1, c-myc and MMP-7 in human pancreatic cancer: relationships with carcinogenesis and metastasis. World $\mathrm{J}$ Gastroenterol 2005, 11:2117-2123

48. Takaku K, Oshima M, Miyoshi H, Matsui M, Seldin MF, Taketo MM: Intestinal tumorigenesis in compound mutant mice of both Dpc4 (Smad4) and Apc genes. Cell 1998, 92:645-656

49. Painuly U, Kumar S: Efficacy of bortezomib as first-line treatment for patients with multiple myeloma. Clin Med Insights Oncol 2013, 7:53-73

50. O'Sullivan Coyne G, Walsh J, Kelly CM: Effectiveness and safety of eribulin mesylate: a new therapeutic option in the treatment of metastatic breast cancer. Expert Opin Drug Saf 2012, 11:643-650

51. Newman S: Eribulin, a simplified ketone analog of the tubulin inhibitor halichondrin $\mathrm{B}$, for the potential treatment of cancer. Curr Opin Investig Drugs 2007, 8:1057-1066

52. Yamaguchi H, Hsu JL, Hung MC: Regulation of ubiquitinationmediated protein degradation by survival kinases in cancer. Front Oncol 2012, 2:15 